\title{
Lexis, Lexical Competence and Lexical Knowledge: A Review
}

\author{
Keiby Caro \\ Universidad del Norte, Colombia; \\ Universidad del Atlántico, Colombia \\ Nayibe Rosado Mendinueta \\ Universidad del Norte, Colombia
}

\begin{abstract}
Lexis is one essential component of language and language development. Limited lexical knowledge can lead EFL learners to frustration and demotivation. To reach a higher level of development in the four basic communication skills, learners should have a basis of lexis that allows them to do so. One of the factors affecting the ongoing development of communicative competence is neglecting the systematic teaching of lexis. Teachers' lack of knowledge of the lexical field has contributed negatively to this current situation. To meet these needs, this article reviews concepts such as lexis/vocabulary, lexical competence and knowledge and size and depth of lexical knowledge. It discusses new perspectives that could help language teachers develop conceptual knowledge to handle lexical instructional practice.
\end{abstract}

Index Terms — vocabulary, lexis, lexical knowledge, competence, breadth and depth

\section{INTRODUCTION}

Teaching and learning lexis has gained relevance in ELT in the last 30 years. Before, this aspect of the language was not a priority for researchers and curriculum developers; it was underestimated for many years (Carter and McCarthy, 1988; Nation, 1990; Zimmerman, 1997; O'dell, 1997; DeCarrico, 2001; Alemi and Tayebi, 2011). This situation changed favorably when researchers realized the predominant role it plays in language learning and teaching (Coady and Huckin, 1997; Griffiths, 2003, 2006; Shen, 2008). Scholarly discussions have produced a "substantial amount of theoretical and empirical studies in the area" (Bee Choo, Tan Ai Lin and Pandian, 2012, p. 853) and, as a consequence, a wide range of concepts and terminologies have emerged.

It is now acknowledged that lexis is an essential component in language acquisition. Limited knowledge of it could lead to learners' frustration since they cannot convey what they want to express when speaking or writing. To this regard, Folse (2004) points out that "however, with poor vocabulary communication is constraint considerably. You can get by without grammar; you cannot get by without vocabulary" (p. 2). This might be overcome by working it systematically to increase lexical competence and overall communicative competence. Nation (1994) agrees that "a rich vocabulary makes the skills of listening, speaking, reading, and writing easier to perform" (p. viii) contributing to effective and successful communication (Alqahtani, 2015). In the EFL context, this requires lexical instruction, which translates theoretical knowledge acquired in the field to the teaching contexts (Thornbury, 2002).

Given the richness and contributions in concepts and terminologies aforementioned, this article attempts to review the ensuing topics:

a) discuss vocabulary and lexis and the favorability of espousing the second one, b) explore the diverse concepts of lexical competence and present a systemic definition, c) put forward definitions of vocabulary or lexical knowledge and frameworks that explain how lexical/vocabulary acquisition occur, as well as d) define size and organization of vocabulary/lexis knowledge and present an alternative model to show the networked interactions between them.

The goal is to shed light on these issues and make suggestions for bridging some conceptual gaps so that teachers may use them as guidelines in EFL lexical instruction and contribute to more systematic and successful learning experiences.

\section{LITERATURE REVIEW}

\section{A. The Difference between Vocabulary and Lexis}

The first concept to be considered for this theoretical review is that of vocabulary or lexis. Some online dictionaries such as the Merriam-Webster (2015) define vocabulary as "The words that make up a language; all of the words known and used by a person: words that are related to a particular subject." Similarly, Cambridge (2016) describes it as "The words that are known or used by a particular person, or that are used in a language or subject." Finally, Macmillan (2009-2016) also presents it as "All the words that a person knows; all the words in a particular language." 
The above definitions are similar to the ones provided by some of the scholars in the field of linguistics and appliedlinguistics. For instance, Linse and Nunan (2005) stress that "Vocabulary is the collection of words that an individual knows." (p. 121). Richards and Schmidt (2010) concur that "Vocabulary is a set of lexemes, including single words, compound words, and idioms" (p. 629). For their part, Kamil and Hiebert (2005) express that "Generically, vocabulary is the knowledge of meanings of words" (p. 3).

Recently, the tem lexis has been introduced and used interchangeably to mean vocabulary. Barcroft, Sunderman, and Schmitt (2011) explain it as follows:

The term lexis, from the ancient Greek for 'word', refers to all the words in a language, the entire vocabulary of a language. Plato and Aristotle spoke of lexis in terms of how the words of a language can be used effectively. (p. 571)

Likewise, Jackson and Amvela (2000) suggest that vocabulary, lexis, and lexicon are synonymous. The idea is supported by Larsen-Freeman and Decarrico (2010) when they write that vocabulary/lexis includes "...not only syntax and morphology but also phonetics, phonology, semantics and lexis (that is, vocabulary)" (p.18). Nonetheless, some others make a distinction between vocabulary and lexis. When people think of vocabulary, they usually relate it to words and meanings. Lexis, on the contrary, is not only associated with words, but expands to include other layers of lexical knowledge. Stephen Van Vlack (2013, July), whose view is shared in this article, illustrates in the figure below the growing levels of complexity from word to lexis.

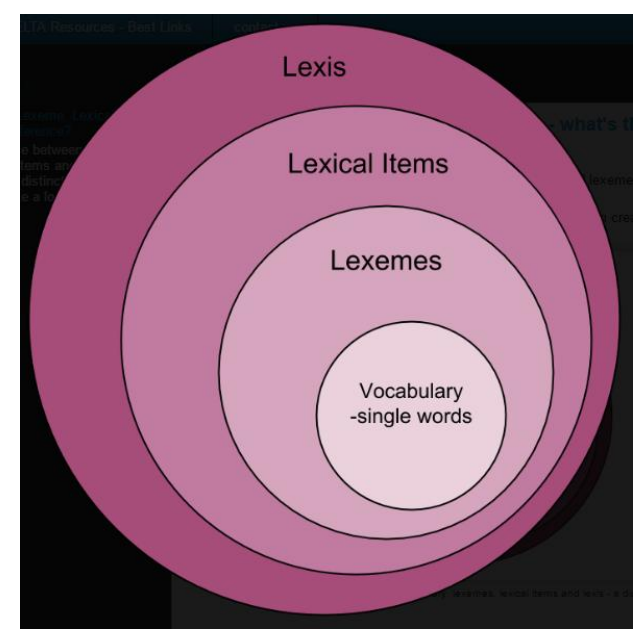

Figure 1. Difference between vocabulary and lexis taken from van Vlack (2013, July)

Discussions on the term lexis explain that it comprises a system of word units, which relates to other units creating a network of meanings ranging from polysemy, collocation, ambiguity, synonymy and frequency (Schmitt \& Meara, 1997; Miller, 1999; Nation, 2001). In contrast, the common and restricted belief in ELT that vocabulary is an "all-ornothing relationship" (Shen, 2008) has favored the teaching of isolated or decontextualized vocabulary lists hampering learners' lexical development. To support the above statement, Al-Batel cited by Wahba, Taha and England (2006) assert that "decontextualized paired vocabulary lists are of limited value to learners if they are not accompanied by context-building activities" (p. 332). For this reason, a broader systemic view deriving from this redefinition of lexis may bring about substantial changes in the way instructed lexical practices are developed.

In the framework of a systemic definition of lexical competence put forward in this review, a matching systemic definition of lexis is required moving beyond the conventional idea of vocabulary (words and meanings), and helping to consolidate the size and depth of lexical knowledge in growing levels of complexity. Such an approach will help teachers gain awareness of the multilayered nature of lexis taking advantage of it to equip learners with the elements required to develop this competence.

\section{B. The Concept of Lexical Competence}

Prior to tackling the concept of lexical competence, it is worth defining what competence is and how it has been viewed so far. The term competence has generated substantial controversy in the field of general and applied linguistics (Chomsky, 1965; Hymes, 1972). The former regarded it as a sheer grammatical competence, that is, "the speakerhearer's knowledge of his language" (p.6) and the latter observed that this competence was more related to communication:

...a normal child acquires knowledge of sentences not only as grammatical, but also as appropriate. He or she acquires competence as to when to speak, when not, and as to what to talk about with whom, when, where, in what manner. In short, a child becomes able to accomplish a repertoire of speech acts, to take part in speech events, and to evaluate their accomplishment by others (Hymes, 1972, p. 277).

In Colombia, the Ministry of Education has defined competence as "the set of knowledge, skills, abilities and individual characteristics that allows a person to perform actions in a given context ..." (MEN, 2006, p. 11, author's translations). This suggests an interrelation of the underlying aspects of competence for people to be able to succeed in 
their daily performance. In coherence with it, lexical competence deals with these components in relation to lexis, which has been embedded within the communicative competence and specifically in the linguistic one, where grammar is listed first and lexis second (Canale \& Swain, 1980; Savignon, 1983; Council of Europe, 2001).

It is believed that the order mentioned above has given prominence to grammar over lexis in English classrooms. In fact, some teachers teach grammar first then lexis. Lee (2004) stresses that "recently, several linguists have proposed the importance of putting lexis, not grammar, at the center of the classroom in order to help learners develop their ability to use English for real communication" (Prioritizing lexis over grammar, paragraph 2). Contrary to this, Lewis (1997, p. vi) points out that "language consists of grammaticalized lexis, not lexicalized grammar"; lexis is essential in the creation of meaning and grammar should be subjected to it and not vice versa. This is also supported by Widdowson (1990) when he expresses it is necessary to move away from this narrow view of language teaching:

Teaching which gives primacy to form and uses words simply as a means of exemplification actually denies the nature of grammar as a construct for the mediation of meaning. I would suggest that the more natural and more effective approach would be to reverse this traditional pedagogic dependency, begin with lexical items and show how they need to be grammatically modified to be communicatively effective (p. 95).

Lexis should then be restored its primacy in language teaching and learning because lexical competence is at the core of communicative competence development.

A simple definition of lexical competence is not easy to pinpoint because of the multifaceted nature of words. Jiménez (2002) highlights this difficulty and groups discussion around this issue as follows:

a) Authors who define, limit or list the dimensions of this competence (Carter, 1987; Nation, 1990; Taylor, 1990; Laufer, 1991; Lahuerta \& Pujol, 1996; Marconi, 1997; Council of Europe, 2001).

b) Those who criticize its definition as a list of dimensions and propose more comprehensive ones (Meara, 1996a, 1996b; Henriksen, 1999).

c) And those whose main goal is to demonstrate the applicability of the lexical competence framework to the teaching of vocabulary (Robinson, 1989; Lennon, 1990; Schmitt, 1995).

One of the definitions is the very general one provided by Marconi (1997) who views it “...as part of overall linguistic competence; more particularly, it is regarded as part of semantic competence, the knowledge and abilities that underlie a speaker's understanding of a language.” (p. 77). A simpler one is provided by The Council of Europe (2001) that defines it as "the knowledge of and ability to use the vocabulary of a language" (p.110).

Meara (1996a) acknowledges that the difficulty in having a thorough definition lies in the lack of a lexical competence framework which implies having "a complete model of semantics, and a complete specification of the syntactic and associational behavior of all the words in a speaker's lexicon. So far, this level of description seems far from being realised" (p. 14).

Existing definitions of lexical competence do not reflect the complexity of it in terms of its components- form, meaning, use- nor the relationships among them. Therefore, a more comprehensive definition is required. One that understands lexical competence as a cluster of knowledge (form, meaning and use of a lexical item), abilities and skills that a person develops and deploys in different contexts of communication. Learners can resort to their mental lexicons and construct varied relationships, which contribute to lexical size and depth by activating knowledge appropriate to the communicative purpose, the interlocutor and the social context.

As this comprehensive definition suggests, lexis is a competence in its own right. Consequently, it should be given salience as a core one, due to its transversality in linguistic, pragmatic and sociolinguistic dimensions of language. We would like to suggest that lexical competence should be addressed as a pivotal language aspect in EFL teaching and learning.

\section{The Definition of Vocabulary/Lexical Knowledge and Frameworks}

Within the framework of lexical competence, vocabulary knowledge also labeled as lexical knowledge is defined by Laufer and Goldstein (2004) as "the sum of interrelated subknowledges" or "...construed as a continuum consisting of several levels of knowledge, starting with superficial familiarity with the word and ending with the ability to use the word correctly in free production" (p. 400).

This definition transcends traditional views, in which learning a word or lexical item is approached as learning the forms and meanings overlooking the cognitive effort and the need of using the word in varied and multiple communicative contexts. Approaching lexical competence from this definition may aid the teacher to be aware of and help students to develop the necessary interrelated subknowledges that constitute it. A traditional approach to tackling vocabulary knowledge teaching and learning has resulted in limited vocabulary learning leading to frustration, disappointment and demotivation, and hampering communication. In Alqahtani's words (2015) “vocabulary knowledge is often viewed as a critical tool for second language learners because a limited vocabulary in a second language impedes successful communication" (p. 2). If learners are not exposed to systematic vocabulary knowledge learning opportunities, their vocabulary or lexical size does not expand. So, learners can have difficulty in comprehending the target language even if they are equipped with grammatical competence. To this regard, Wilkins (1972) states the following: "There is not much value in being able to produce grammatical sentences if one has not got the vocabulary that is needed to convey what one wishes to say ... While without grammar very little can be conveyed, without vocabulary nothing can be conveyed"' (pp.110-111). 
In a more complex oriented perspective of word/lexical knowledge, Moghadam, Zainal and Ghaderpour (2012) mention some aspects that characterize this view of vocabulary/ lexical knowledge:

Researchers have taken notice of the multidimensionality and complication of word knowledge, suggesting that knowing a word completely should include various kinds of linguistic knowledge ranging from pronunciation, spelling, and morphology ... and ... to knowledge of the word's syntactic and semantic relationships with other words in the language, involving knowledge of antonym, synonymy, hyponym and collocational meanings... (pp. 556-557).

As highlighted above, vocabulary or lexical knowledge is multilayered. Richards (1976) outlines a framework for knowing a lexical item: breadth of vocabulary, depth of vocabulary, context, syntactic behavior, underlying form, associations, semantic value and different meanings. Following Richards', some other authors have proposed various frameworks that summarized the identified layers:

TABLE I

LEXICAL KNOWLEDGE FRAMEWORKS

\begin{tabular}{|l|l|}
\hline & Dimensions \\
\hline 1) Chapelle (1998) & $\begin{array}{l}\text { a) vocabulary size } \\
\text { b) knowledge of word characteristics } \\
\text { c) lexicon organization, and } \\
\text { d) processes of lexical access (p. 37). }\end{array}$ \\
\hline 2) Henriksen (1999) & $\begin{array}{l}\text { a) "partial-precise knowledge } \\
\text { b) depth of knowledge, and } \\
\text { c) a "receptive to productive use ability" (p.303). }\end{array}$ \\
\hline 3) Nation (2001) & $\begin{array}{l}\text { a) form: spoken form, written form, and word parts } \\
\text { b) meaning: form and meaning, concept and reference, and associations; and } \\
\text { c) use: grammar, collocations, and constraints on use (pp. 124-125). }\end{array}$ \\
\hline 4) Qian (2002) & $\begin{array}{l}\text { a) vocabulary size } \\
\text { b) depth of vocabulary knowledge } \\
\text { c) lexical organization, and } \\
\text { d) automaticity of receptive-productive knowledge (p. 515). }\end{array}$ \\
\hline
\end{tabular}

As depicted by the authors in their frameworks, lexical knowledge is not just a simple relationship between form and meaning or "an all-or-nothing phenomenon, but involves degrees of knowledge. They suggest it should be constructed as a continuum, or continua, consisting of several levels and dimensions of knowledge" (Shen, 2008, p.136). These models seem to suggest that the progression from one level or dimension to the other is linear in the continuum.

Meara (1996b) criticizes this view because it does not represent the open nature of lexical knowledge development, which is far from being linear. Due to this, he proposes an alternative, in which the progression from layer to layer of lexical knowledge is multistate (see Figure 2). In this model, there are five states ranging from 1 to 5 and state $o$ represents an unknown lexical item. Each state is independent and learners can go from one state to another without following a specific order. It recognizes the open nature of lexical knowledge development and the fact that learners might forget or learn lexical items at any state.

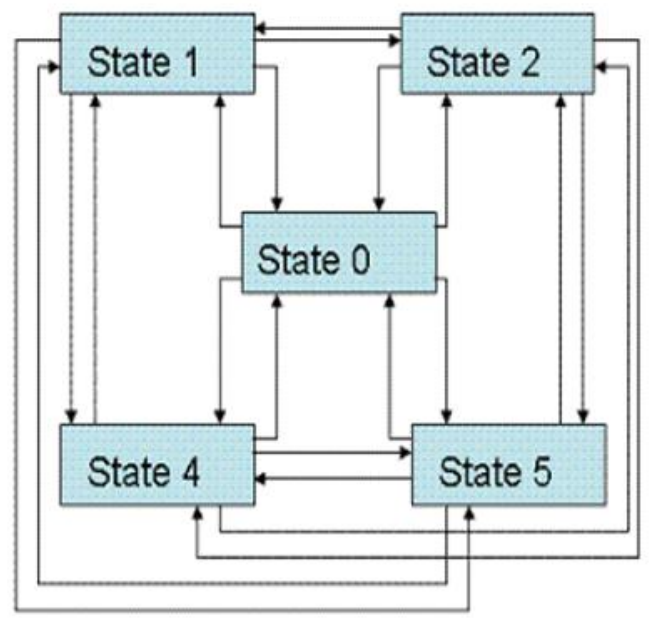

Figure 2. A multistate model of lexical acquisition taken from Meara (1996b)

In our view, Meara's position seems to depict better EFL learners' processes of learning lexical items. For instructional purposes, though, whatever the framework is, lexical knowledge instruction should provide opportunities to develop lexical growth and depth since they are vital tools to access the other skills (Qian, 1999).

D. Breadth and Depth of Lexical Knowledge

\section{Breadth of lexical knowledge}


It is estimated that the number of word families in the English language is approximately between 88.500 (Nagy \& Anderson, 1984) and 114.000 (Goulden, Nation, \& Read, 1990). According to Nation (2001, 2006), a well-educated native speaker can have 20.000 word families and they increase at a rate of about 1000 of them a year. Some other authors have calculated that EFL students require a number of 5,000 word families for reading (Hirsh and Nation, 1992), between 6,000 and 7,000 for listening and between 8,000 and 9,000 for reading (Nation, 2006). Hazenberg and Hulstun, (1996) acknowledge that around 10,000 word families are needed for a student to deal with academic English at a university level. However, most foreign language learners can hardly add 250 of these word families in the same period of time of a native speaker (Nation, 2001).

As highlighted from the examples above, lexical breadth is what a learner knows and can do at a particular level of competence (Nation, 2001a; Qian, 2002), Daller, Milton, and Treffers-Daller (2007) consider it as “...the number of words a learner knows regardless of how well he or she knows them" (p.7) and Wang (2009) states that “...breadth of vocabulary knowledge (or vocabulary size), means the estimated number of words that a learner knows" (p.202).

Breadth of lexical knowledge is mostly associated with the number of words (size) a person knows; however, not much has been said about the quality of the lexical items learned. EFL teachers should plan for lexis to be continuously expanded through lessons, courses, and the curriculum giving learners opportunities to explore the connections between lexical choices and the purpose of communicative events, making evident the need to expand the lexis to match those purposes.

In order to measure the lexical breadth knowledge in ELT, there are tests such as the Vocabulary Size Test (VST) known as Lex 30 (Meara and Fitzpatrick, 2000). The VST is subdivided into receptive and productive (Nation and Beglar, 2007).

2. Depth of lexical knowledge

Knowing a lexical item goes beyond the boundaries of mastering its spelling and pronunciation. This knowledge is not restricted to a single dimension, but refers to a multidimensional construct. Below there is a series of definitions and analyses in light of the current literature:

TABLE 2

DEFINITIONS AND ANALYSIS

\begin{tabular}{|l|l|}
\hline Author & Definition \\
\hline Read (1993) & $\begin{array}{l}\text { "...the quality of the learner's vocabulary } \\
\text { knowledge (how well are particular words known?)" (p.357). }\end{array}$ \\
\hline Qian (1998) & $\begin{array}{l}\text { Pronunciation and spelling; morphological properties; syntactic properties; meaning; } \\
\text { register, or discourse features and frequency of the word in the language (pp. 24-25) }\end{array}$ \\
\hline Shen (2008) & $\begin{array}{l}\text { "Depth of knowledge focuses on the idea that for useful higher-frequency words learners } \\
\text { need to have more than just a superficial understanding of the meaning" (p. 136). }\end{array}$ \\
\hline Moghadam et al. (2012) & $\begin{array}{l}\text { "Depth of knowledge is a network of links between words. It is about how they associate } \\
\text { and interact with each other, and may be restricted in use according to register and context" } \\
\text { (p. 558). }\end{array}$ \\
\hline
\end{tabular}

The above definitions seem limited, linear and center on the quality of knowledge of the learned lexical items, and tend to lack the context where the items can be used. The authors make a list of the most relevant aspects of knowing a lexical item reflecting a somewhat shallow understanding of the systemic linked network process activated when the lexical items are interacting with others. Moghadam et al's (2012) is much more comprehensive and encompasses most of the elements regarding the way the lexical items interact when users retrieve them from their lexicon.

According to Rashidi and Khosravi (2010), the depth of lexical knowledge is considered as one of the main dimensions because it strengthens reading comprehension. Breadth and depth of lexical knowledge are determinant in moving learners further in their general competence development, therefore instructional planning should address lexical knowledge instruction explicitly offering ample opportunities for lexical growth and depth to guarantee language development and learning (Qian, 1999).

In order to measure the lexical depth knowledge, the Word Associates Test (WAT) (Read, 1998) has been widely utilized.

\section{An alternative model to lexical breadth and depth knowledge}

Meara and Wolter (2004) suggest renaming the terms breadth and depth for "size and structure or size and organization" (p.89) respectively. This change of terminologies is based on the understanding of the interaction produced when lexical items are learned and used. He highlights that L2 lexicons act differently from L1 lexicons in the sense that the former are less structured, developed and complex than the latter ones. In order to illustrate this, he proposes a model where the interactions are represented in a network connected with nodes (breadth or size). These nodes are increased as a learner adds new lexical items to his or her lexicon forming new links to the already existing ones. This model is shown in figure 3: 
Vocabulary breadth and depth

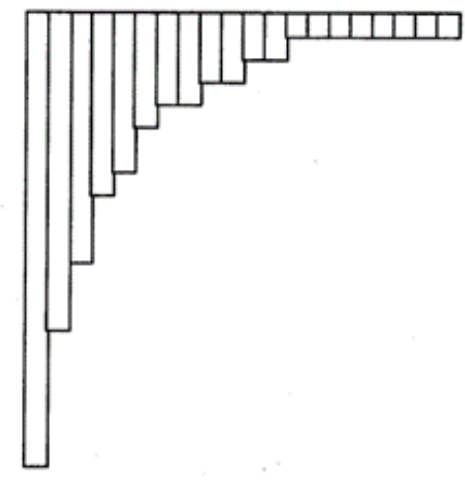

Vocabulary size and organisation

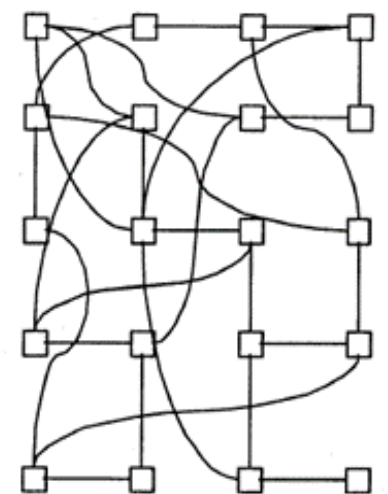

Figure 3. An alternative model to lexical breadth and depth from Meara and Wolter (2004, p.89)

In Meara and Wolter's words (2004), this model is an innovative alternative to the traditional conception of how lexis is learned. They contrast the diagram on the left with the one on the right. The first depicts the current position of many theorists favoring the linear model where there are no interactions, links or associations among lexical items. They just limit to two axes: one is breadth and the other depth, whose length of the bars show the lexical depth knowledge. The second one stands for a more interactive approach where the boundaries of breadth (size) and depth (organization) are not completely closed and are interconnected through nodes. These nodes represent learners' lexical size. The lexical items form connections in a network, linking the existing knowledge with previous knowledge strengthening depth and affecting the rest of the network in the process.

In agreement with the model devised by Meara and Wolter (2004), this review adopts the idea that the learning of lexical items is not static. The brain stores them in semantic fields and learners retrieve them according to their needs depending on the communicative contexts. When using the items, they make connections with others expanding (size) and deepening (organization) the existing ones through networks. Consequently, the traditional and linear conception of lexical breadth and depth, where the lexical items do not make connections with some other ones and where the relationship between breadth and depth lack interconnection, should be revisited in light of this alternative approach.

\section{Some PedAgOgICAL IMPLICATIONS}

To help learners develop their lexical competence, lexical instruction in the classroom settings should be informed by current theoretical understandings.

Coady (1997) cited in Duppenthaler (2007) numbers four aspects for teachers to have an impact when teaching lexis: “(1) the teacher's own learning experiences, (2) the teacher's metacognitive attitude toward learning vocabulary, (3) the teacher's knowledge of the research in the field, and (4) the effect of experiences gained through teaching" (p.4). Once teachers have gained experience and knowledge in this field, they can put into practice an affective framework to teach it.

To this regard, Hunt and Beglar (2002) propose a systematic framework to lexis teaching and learning. It ranges from incidental learning, explicit instruction to independent strategy development. They state that incidental learning is when learners acquire lexis through reading and listening. They add that teachers should focus on it with proficient intermediate and advanced learners. Explicit instruction refers to actually teach strategies and lexis directly. Hunt and Beglar suggest teachers should carry it out to beginners and intermediate learners with limited lexis. Finally, independent strategy development so that learners can become autonomous.

Teachers should become aware of their current understanding of lexis, lexical competence, lexical knowledge and components and support curricular and instructional decisions on a profound understanding of principles of communicative language teaching and learning. To this regard, we suggest:

Always consider the communicative situation or need: Lexis is learned as a response to communicative needs, so teachers should think of meaningful communicative contexts and delineate networks or clusters of lexis that could respond to the needs or contextual situations. It is also important to leave room for students' contributions to the network.

Lexical competence: when considering lexical instruction, it is worth contemplating both the knowledge and the skills embedded in the concept. Teachers should include ample opportunities for lexical knowledge and skills development allowing learners to be exposed, to store, to use and retrieve lexis from the learned clusters and networks, making sure to activate different ways to store and retrieve the lexical subknowleges and offering them opportunities to adapt to varied communicate contexts, so they are able to develop pragmatic and sociocultural lexical awareness and skills conducing to effective communication. 
Size and organization: lexical instruction should be systematically and intentionally planned within the curriculum and outside of it. A spiral networked approach to the teaching and learning of lexis in a communicative competence informed curriculum should establish the basis for autonomous and independent lexical development regarding size and organization.

\section{CONCLUSION}

In the article, it was argued that the concepts of lexis, lexical competence, lexical knowledge, and breadth and depth of lexical knowledge should be revisited to include current discussions in the field. Lexis differs from the traditional term vocabulary, which in our view restricts its meaning. Lexis is broader and engulfs vocabulary, lexemes and lexical items. Lexical competence was also reviewed and a new definition was presented in this article, which encompasses lexical knowledge and its use in diverse contexts. We also suggest that knowing a word implies more than mastering a form and a meaning. A range of lexical knowledge frameworks with their dimensions were outlined and commented. However, they do not seem to reflect the way lexical competence is developed in EFL learners. In this regard, Meara's multistate model of lexical acquisition (1996b) seems to be more effective to explain the complexity of the process. Other aspects discussed were breadth and depth of lexical knowledge. These were tackled from an alternative approach suggested by Meara and Wolter (2004), where lexical items are interconnected and form networks or associations unlike the linear view. Some considerations are put forward at the end with the aim of helping teachers in their decision making regarding lexical instruction.

\section{REFERENCES}

[1] Al-Batal, M. (2006). Playing with words: teaching vocabulary in the Arabic curriculum. In K. Wahba, Z. Taha \& L. England (Eds.), Handbook Arabic language teaching professionals in the 21st century (pp. 331-340). New Jersey, USA: Routledge.

[2] Alquahtani, M. (2015). The importance of vocabulary in language learning and how to be taught. International Journal of Teaching and Education 3.3, 21-34.

[3] Alemi, M., \& Tayebi, A. (2011). The influence of incidental and intentional vocabulary acquisition and vocabulary strategy use on learning L2 vocabularies. Journal of Language Teaching and Research 2.1, 81-98.

[4] Barcroft, J., Schmitt, N., \& Sunderman, G. (2011). Lexis. In J. Simpson (Ed.), The Routledge Handbook of Applied Linguistics (p. 571-583). Abingdon, UK / New York: Routledge.

[5] Bee Choo, L., Tan Ai Lin, D., \& Pandian, A. (2012). Language learning approaches: A review of research on explicit and implicit learning in vocabulary acquisition (pp. 852-860). Procedia-Social and Behavioral Sciences 55. Elsevier.

[6] Canale, M., \& Swain, M. (1980). Theoretical bases of communicative approaches to second language teaching and testing. Applied Linguistics 1.1, 1-47.

[7] Carter, R., \& McCarthy, M. (Eds). (1988). Vocabulary and language teaching. New York: Longman.

[8] Chapelle, C.A. (1998). Construct definition and validity inquiry in SLA research. In Bachman, L.F. and Cohen, A.D. (Eds.), Interfaces between second language acquisition and language testing research (pp. 32-70). Cambridge: Cambridge University Press.

[9] Chomsky, N. (1965). Aspects of the theory of syntax. THE M.LT. PRESS. Cambridge, Massachusetts-USA.

[10] Coady, J., \& Huckin, T. (Eds.). (1997). Second language vocabulary acquisition. Cambridge: Cambridge University Press.

[11] Council of Europe. (2001). A Common European Framework of Reference for Languages: Learning, Teaching, Assessment. Cambridge: CUP.

[12] Daller, H., Milton, J., \& Treffers-Daller, J. (2007). Modelling and assessing vocabulary knowledge. Cambridge: Cambridge University Press.

[13] DeCarrico, J. (2001). Vocabulary learning and teaching. In Teaching English as a second or foreign language (pp. 285-299). Celce-Murcia, Marianne (ed.). Boston: Heinle and Heinle.

[14] Duppenthaler (2007). Vocabulary Acquisition: The Research and Its Pedagogical Implications. http://ci.nii.ac.jp/naid/110006558440 (accessed 1/5/2016).

[15] Folse, K. (2004). Myths about teaching and learning second language vocabulary: what research says. TESL Reporter 37. 2, 113.

[16] Goulden, R., Nation, P., \& Read, J. (1990). How large can a receptive vocabulary be? Applied Linguistics 11.4, $341-363$.

[17] Griffiths, C. (2003). Patterns of language learning strategy use. System 31, 367-383.

[18] Griffiths, C. (2006). Language learning strategies: Theory and research. Iran. ILI Language Teaching Journal 2. 1, 1-29.

[19] Hazenberg, S., \& Hulstun, J. H. (1996). Defining a minimal receptive second-language vocabulary for non-native university students: An empirical investigation. Applied Linguistics, 17.2, 145-163.

[20] Henriksen, B. (1999). Three dimensions of vocabulary development. Studies in Second Language Acquisition 3, 303-317.

[21] Hirsh, D., \& Nation, I. S. P. (1992). What vocabulary size is needed to read unsimplified texts for pleasure? Reading in a foreign language 8.2, 689-696.

[22] Hunt, A. \& Beglar, D. (2002). Current Research and Practice in Teaching Vocabulary. In J. Richards \& W. Renandya (Eds.), Methodology in language teaching: an anthology of current practice (pp. 258-266). New York: Cambridge University Press.

[23] Hymes, Dell H. (1972). On communicative competence. In Pride, J.B.; Holmes, J. Sociolinguistics: selected readings (pp. 269293). Harmondsworth: Penguin.

[24] Jackson, H., \& Amvela, E. (2000). Words, meaning, and vocabulary: an introduction to modern English lexicology. London; New York: Cassell, - Open linguistics series.

[25] Jiménez, R. (2002). El concepto de competencia léxica en los estudios de aprendizaje y enseñanza de segundas lenguas. Atlantis, 24.1, 149-162. 
[26] Kamil, M., \& Hiebert, E. (2005). Teaching and learning vocabulary: Perspectives and persistent issues. In E. H. Hiebert and M. L. Kamil (Eds.), Teaching and learning vocabulary: Bringing research to practice (pp. 1-23). Mahwah, NJ: Lawrence Erlbaum.

[27] Lahuerta, J., \& Mercé, P. (1996). El lexicón mental y la enseñanza del vocabulario. La enseñanza del léxico español como lengua extranjera. Ed. Carlos Segoviano. Frankfurt am Main y Madrid. Iberoamericana. 1, 17-29.

[28] Laufer, B. (1991). Knowing a word: What is so difficult about it? English Teachers' Journal 42, 82-88.

[29] Laufer, B., \& Goldstein, Z. (2004). Testing vocabulary knowledge: Size, strength, and computer adaptiveness. Language Learning, 54.3, 399-436.

[30] Larsen-Freeman, D., \& DeCarrico, J. (2010). Introduction: Grammar and grammars. In N. Schmitt (Ed.), An introduction to applied linguistics (2nd ed., pp. 18-33). London: Hodder Education.

[31] Lee, S. (2004). Teaching lexis to EFL students: a review of current perspectives and methods. ARECLS, Volume 1. http://research.ncl.ac.uk/ARECLS/vol1_documents/Seowon/Seowon.htm (accessed 1/6/2016).

[32] Lennon, P. (1990). The bases for vocabulary teaching at the advanced level. I.T.L 87-88, 1-22.

[33] Lewis, M. (1993). The lexical approach: The state of ELT and the way forward. Hove, England: Language Teaching Publications.

[34] Linse, C., \& Nunan, David. (2005). Practical English language teaching: young learners. New York, NY: McGrawHill/Contemporary.

[35] Marconi, D. (1997). Lexical Competence Language, Speech, and Communication. London. MIT Press.

[36] Meara, P. (1996a). The dimensions of lexical competence. In Brown, G., Malmkjaer, K. and Williams, J. (eds.) Performance and competence in second language acquisition (pp.35-53). Cambridge: Cambridge University Press.

[37] Meara, P. (1996b). The Vocabulary Knowledge Framework, www.lognostics.co.uk/vlibrary/index.htm (accessed 19/4/2016).

[38] Meara, P., \& Fitzpatrick, T. (2000). Lex30: An improved method of assessing productive vocabulary in an L2. System, 28, 1930. doi:10.1016/S0346-251X(99)00058-5.

[39] Meara, P. (2002). The rediscovery of vocabulary. Second Language Research 18. 4, 393-407.

[40] Meara, P., \& Wolter, B. (2004). V_links: beyond vocabulary depth. Angles on the English-speaking world 4, 85-96.

[41] Miller, G. (1999). On knowing a word. Annu. Rev. Psychol. 1999. 50, 1-19.

[42] Ministerio de Educación Nacional. (2006). Serie Guías No 22 Estándares Básicos de Competencias en Lenguas Extranjeras: Inglés. Bogotá-Colombia.

[43] Moghadam, S., Zaidah, Z., \& Ghaderpour, M. (2012). A review on the important role of vocabulary knowledge in reading comprehension performance. Procedia - Social and Behavioral Sciences 66, 555-563.

[44] Nagy, W.E., \& Anderson, R.C. (1984). How many words are there in printed school English? Reading Research Quarterly, $19.3,304-330$.

[45] Nation, I. S. P. (1990a). Teaching and learning vocabulary. New York: Newbury House.

[46] Nation, I.S.P. (1990b). What is involved in learning a word? In P. Nation Teaching and Learning Vocabulary (pp. 29-50). New York: Newbury House.

[47] Nation, I. S. P. (1994). New ways in teaching vocabulary. Alexandria, VA: TESOL.

[48] Nation, I. S. P. (2001a). Learning vocabulary in another language. UK. Cambridge University Press.

[49] Nation, I.S.P. (2001b). How good is your vocabulary program? ESL Magazine 4. 3, 22-24.

[50] Nation, I.S.P. (2006). How large a vocabulary is needed for reading and listening? Canadian Modern Language Review 63.1 , 59-82.

[51] Nation, I.S.P., \& Beglar, D. (2007). A vocabulary size test. The Language Teacher 31. 7, 9-13.

[52] Nation, I.S.P., \& Moir, J. (2008). Vocabulary learning and the good language learner. In Carol Griffiths (ed) Lessons from Good Language Learners. Cambridge: Cambridge University Press.

[53] O'dell, F. (1997). Incorporating vocabulary into the syllabus. In N. Schmitt, \& M. McCarthy (Eds.), Vocabulary: Description, acquisition and pedagogy (p. 258-278). Cambridge: Cambridge University Press.

[54] Online Merriam Webster Dictionary. (2015). http://www.merriam-webster.com/dictionary/vocabulary (accessed 21/5/2016).

[55] Online Cambridge Dictionary. (2016). http://dictionary.cambridge.org/es/diccionario/ingles-espanol/vocabulary (accessed 21/5/2016).

[56] Online Macmillan Dictionary. (2009-2016). http://www.macmillandictionary.com/dictionary/british/vocabulary (accessed 21/5/2016).

[57] Qian, D.D. (1998). Depth of vocabulary knowledge: assessing its role in adults' reading comprehension in English as a second language (doctoral thesis). University of Toronto, Canada.

[58] Qian, D. D. (1999). Assessing the roles of depth and breadth of vocabulary knowledge in reading comprehension. Canadian Modern Language Review, 56, 282-308.

[59] Qian, D.D. (2002). Investigating the relationship between vocabulary knowledge and academic reading performance: an assessment perspective. Language Learning 52. 3, 513-536.

[60] Rashidi, N., \& Khosravi, N. (2010). Assessing the role of depth and breadth of vocabulary knowledge in reading comprehension of Iranian EFL learners. Pan-Pacific Association of Applied Linguistics 14.1, 81-108

[61] Read J. (1993). The development of a new measure of L2 vocabulary knowledge. Language Testing; 10. 3, 355-371.

[62] Read, J. (1998). Validating a test to measure depth of vocabulary knowledge. In A. Kunan (Ed.), Validation in language assessment (p. 41-60). Mahwah, NJ: Lawrence Erlbaum Associates.

[63] Richards, J. (1976). The role of vocabulary teaching. Tesol Quarterly. 10. 1, 77-89.

[64] Richards, J., \& Schmidt, R. (2010). Longman Dictionary of Language Teaching \& Applied Linguistics (4th edition). Essex: Pearson Education Limited.

[65] Robinson, P. (1989). A rich view of lexical competence. ELT Journal 43.4, 274- 81.

[66] Savignon, S. J. (1983). Communicative Competence: Theory and Classroom Practice. Texts and Contexts in Second Language Learning. Reading, Massachusetts at all: Addison-Wesley Publishing Company. 
[67] Schmitt, N. (1995). A fresh approach to vocabulary: using a word knowledge framework. RELC Journal 26.1, 86-94.

[68] Schmitt, N., \& Meara, P. (1997). Researching vocabulary through a word knowledge framework. SSLA, 20, 17-36.

[69] Shen, Z. (2008). The Roles of Depth and Breadth of Vocabulary Knowledge in EFL Reading Performance. Asian Social Science. 12, 135-137.

[70] Taylor, L. (1990). Teaching and Learning Vocabulary. London: Prentice Hall.

[71] Thornbury, S. (2002). How to teach vocabulary. England. Pearson-Longman.

[72] Zimmerman, C. B. (1997). Historical trends in second language vocabulary instruction. In J. Coady, \& T. Huckin (Eds.), Second language vocabulary acquisition (p. 5-19). Cambridge: Cambridge University Press.

[73] Van Vlack, S. (2013, July). Lexis, Vocabulary, Lexeme, Lexical item - what's the difference? [Web log post]. http://delta3modules.blogspot.com.co/2013/07/lexis-vocabulary-lexeme-lexical-item.html (accessed 3/5/2016).

[74] Wang, H. (2009). Phrasal verbs and breadth of vocabulary knowledge in second language reading: an exploratory study. The journal of Asia TEFL 6. 3, 201-226.

[75] Widdowson, H. G. (1990). Aspects of Language Teaching. Oxford: Oxford University Press.

[76] Wilkins, D. (1972). Linguistics in language teaching. London: Edward Arnold.

Keiby Caro is an education professional with over 20 years of experience in teaching EFL in Colombia. In addition to having classroom experience, he also has expertise in administrating language department faculty. He holds an undergraduate degree from Universidad del Atlántico, a master's degree in Education from Universidad del Norte and is currently a PhD in Education student at this university. All in all, he is a committed and knowledgeable 21st century educator.

Nayibe Rosado Mendinueta is a language teacher and teacher educator. She holds a Diploma in the Teaching of English as a Foreign Language (TEFL) and a M.A. in Education from Universidad del Norte and she is a the Doctor in Sciences of Education. Member of the research group Lenguaje y Educación. Research interests: Teacher learning, Student learning, Complexity, Technology in Language Teaching, Development of language competence. 